\title{
KH Domain
}

National Cancer Institute

\section{Source}

National Cancer Institute. KH Domain. NCI Thesaurus. Code C14092.

First identified in human hnRNPK protein, the conserved KH Domain of around 45-70 amino acids is present in a variety of nucleic acid-binding proteins. The domain may bind RNA in vivo. KH motifs are found in one or multiple copies, interspersed with RGG repeats, that may function cooperatively or, in single motif proteins, independently. $\mathrm{KH}$ domains can be separated into two groups: type-1 (beta-alpha-alpha-beta-beta-alpha) and type-2 (alpha-beta-beta-alpha-alpha-beta). The VIGXXGXXI sequence is preserved in the RNA binding motif between helix 1 and 2 (type-1) and helix 2 and 3 (type-2). The beta sheets are supported by alpha helixes. (NCl) 